\title{
NITROGEN LOSS BY EROSION FROM MECHANICALLY TILLED AND UNTILLED SOIL UNDER SUCCESSIVE SIMULATED RAINFALLS
}

\author{
Julieta Bramorski ${ }^{(1) *}$, Paulo Cesar Ocheuze Trivelin ${ }^{(2)}$ and Silvio Crestana $^{(3)}$ \\ (1) Universidade de São Paulo, Programa de Pós-graduação em Ciências da Engenharia Ambiental, São Carlos, São Paulo, Brasil. \\ (2) Universidade de São Paulo, Centro de Energia Nuclear na Agricultura, Piracicaba, São Paulo, Brasil. \\ (3) Empresa Brasileira de Pesquisa Agropecuária, Embrapa - Instrumentação, São Carlos, São Paulo, Brasil. \\ * Corresponding author. \\ E-mail: bramorski@gmail.com
}

\begin{abstract}
The description of the fate of fertilizer-derived nitrogen $(\mathrm{N})$ in agricultural systems is an essential tool to enhance management practices that maximize nutrient use by crops and minimize losses. Soil erosion causes loss of nutrients such as $\mathrm{N}$, causing negative effects on surface and ground water quality, aside from losses in agricultural productivity by soil depletion. Studies correlating the percentage of fertilizer-derived N (FDN) with soil erosion rates and the factors involved in this process are scarce. The losses of soil and fertilizer-derived $\mathbf{N}$ by water erosion in soil under conventional tillage and no tillage under different rainfall intensities were quantified, identifying the intervening factors that increase loss. The experiment was carried out on plots $(3.5 \times 11 \mathrm{~m})$ with two treatments and three replications, under simulated rainfall. The treatments consisted of soil with and soil without tillage. Three successive rainfalls were applied in intervals of $24 \mathrm{~h}$, at intensities of $30 \mathrm{~mm} / \mathrm{h}, 30 \mathrm{~mm} / \mathrm{h}$ and $70 \mathrm{~mm} / \mathrm{h}$. The applied $\mathrm{N}$ fertilizer was isotopically labeled $(15 \mathrm{~N})$ and incorporated into the soil in a line perpendicular to the plot length. Tillage absence resulted in higher soil losses and higher total nitrogen losses (TN) by erosion induced by the rainfalls. The FDN losses followed another pattern, since FDN contributions were highest from tilled plots, even when soil and TN losses were lowest, i.e., the smaller the amount of eroded sediment, the greater the percentage of FDN associated with these. Rain intensity did not affect the FDN loss, and losses were greatest after less intense rainfalls in both treatments.
\end{abstract}

Keywords: ${ }^{15 N}$, rainfall simulation, water erosion. 


\title{
RESUMO: PERDA DE NITROGÊENIOPOR EROSÃO EM SOLOS MOBILIZADO POR PREPARO MECÂNICO E SEM MOBILIZAÇÃO, SOB CHUVAS SIMULADAS SUCESSIVAS
}

\begin{abstract}
A caracterização do destino do $N$ proveniente do fertilizante em um sistema é uma ferramenta essencial para a melhoria de práticas de manejo que visem a máxima utilização do nutriente pela cultura e o mínimo de perdas. A erosão do solo ocasiona perda de nutrientes, como o $N$, causando impactos negativos na qualidade das águas de mananciais superficiais e subterrâneas, além da queda de produtividade agrícola em razão do empobrecimento do solo. Estudos que correlacionam o percentual de $N$ proveniente do fertilizante com as taxas de erosão do solo, bem como os fatores intervenientes nesse processo, são escassos. Nesse sentido, foram quantificadas as perdas de solo e $N$ provenientes do fertilizante por erosão hídrica em solo mobilizado pelo preparo convencional e solo sem mobilização, sob diferentes intensidades de chuva, identificando os fatores que interferem no aumento dessa perda. O experimento foi conduzido em parcelas experimentais de 3,5 $\mathrm{m}$ de largura e $11 \mathrm{~m}$ de comprimento, com dois tratamentos e três repetições, sob chuva simulada. Os tratamentos utilizados foram solos com mobilização e sem mobilização. Foram aplicadas três chuvas sucessivas, com intervalo de 24 h entre elas, com intensidades de $30 \mathrm{~mm} / \mathrm{h}, 30 \mathrm{~mm} / \mathrm{h}$ e $70 \mathrm{~mm} / \mathrm{h}$. O fertilizante nitrogenado utilizado foi marcado isotopicamente $(15 \mathrm{~N})$ e incorporado ao solo em linha transversal ao comprimento das parcelas. A ausência de preparo do solo condiciona as maiores perdas de solo por erosão e maiores perdas de nitrogênio total (NT) ao longo das chuvas aplicadas. As perdas do nitrogênio proveniente do fertilizante (NPF) seguiram padrão distinto; as maiores perdas de NPF foram verificados nas parcelas com mobilização do solo, mesmo que tenham apresentado as menores perdas de solo e NT; ou seja, quanto menor a quantidade de sedimentos erodidos maior o percentual de NPF associado a esses. As chuvas de maior intensidade não influenciaram a perda de NPF; as maiores perdas ocorreram em decorrência das chuvas de menor intensidade nos dois tratamentos utilizados.
\end{abstract}

Palavras-chave: ${ }^{15 N}$, chuva simulada, erosão hídrica.

\section{INTRODUCTION}

Soil erosion leads to nutrient losses (Favaretto, 2002; Bertol et al. 2003; Guadagnin. 2003; Guadagnin et al, 2005), with potentially negative impacts on water quality of surface and ground water sources, as well as on the air (Follett and Walker, 1989; Antweiler et al., 1996; Favaretto, 2002; Delgado et al., 2008). Losses of soil and associated elements can damage the environment, e.g., by siltation and eutrophication of waterways, and affect farmers and society by economic losses (Cardoso et al., 2012).

Runoff is responsible for the contamination of water bodies, by the transfer of colloidal sediments containing nutrients at generally high concentrations. The amount of transported nutrients is influenced by the soil management system. In general, nutrient concentrations in runoff are higher in systems of soil conservation management, while total nutrient losses are higher in conventional systems (Guadagnin et al., 2005).

Water erosion from soil is influenced by the rain, soil type, topography, soil cover and management, and by conservation practices. Among these factors, soil cover and management have most influence on water erosion (Cogo, 1981); the influence of soil management was described in numerous studies (Cassol and Lima, 2003; Cogo et al., 2003; Bertol et al., 2007; Panachuki et al., 2011).
According to Cogo et al. (2003), although a series of studies showed the effectiveness of conservation tillage in the control of erosion, water losses are extremely variable and may sometimes be higher in no-tillage, sometimes in reduced tillage systems, or sometimes under conventional tillage, or even similar between the different methods of soil tillage methods, determined by conditions such as rain intensity, soil type, topography and crop sequence/rotation used in farm management systems.

Runoff is the most important climatic factor for erosion, with a harmful action; it occurs when the stability established over time between soil, vegetation and soil organisms is upset, usually by human intervention (Mehl, 2000). Beutler et al. (2006) claimed that rain and runoff together are the main active agents of water erosion. The combination of these agents with terrain-related factors determines the intensity of soil degradation.

Among the essential nutrients for high yields in tropical agriculture, nitrogen is one of the most important (Döbereiner, 1997), with the highest crop requirement and the most exported by crops, being the first nutrient to become deficient in a system. This justifies the need to study the influence of the different factors that influence the loss of this nutrient by water erosion in detail.

The characterization of fertilizer $\mathrm{N}$ in agricultural systems is an essential tool for improving management practices aimed at maximum nutrient exploitation by crops and minimal losses (Fenilli et al., 2008). 
The use of isotope-enriched fertilizer $\left({ }^{15} \mathrm{~N}\right)$ is an excellent tool for this type of research (Reichardt and Bacchi, 2004).

Many studies using this tool address the percentage of fertilizer-derived $\mathrm{N}$ (FDN) taken up by crops and/or, FDN losses in runoff water (Carranca et al., 1999; Choi et al., 2003; Bertol et al., 2005; Mead et al., 2008; Giacomini et al., 2010; Woodward et al., 2012; Vallano and Sparks, 2013). Studies correlating the percentage of FDN with soil erosion rates and with the factors involved in this process are scarce.

In this context, the study objective was to quantify losses of soil and fertilizer-derived $\mathrm{N}$ by water erosion from tilled and untilled soil under different rainfall intensities, identifying the intervening factors that increase loss.

\section{MATERIAL AND METHODS}

\section{Description of experimental plots}

This field study was conducted in an experimental area of Sudeste (Fazenda Canchim), UTM coordinates 206219, 7569671, in São Carlos, São Paulo. The soil at the experimental site was classified as Latossolo Vermelho-Amarelo álico, according to the Brazilian System of Soil Classification - SiBCS (Embrapa, 2013). The horizon has moderate, medium texture and $3 \%$ slope, under long-standing use in experiments with no-tillage oat.

The experimental area was structured in downslope plots (width $3.5 \mathrm{~m} \times$ length $11 \mathrm{~m}$ ). Each plot was delimited at the far ends by plywood boards (width $0.20 \mathrm{~m}$, driven halfway into the soil). At the lower end a hole was spared, to which a PVC pipe was fixed to channel the runoff to a $1.0 \mathrm{~m}^{3}$ collector box.

Two treatments were used: plots with tilled soil (TS) (plowing and disking) and with untilled soil (US), with three replications. The soil was prepared in mid-February, and in both treatments the soil was maintained completely bare during the experiment, removing even the residues of the previous crop. The experiment was conducted between February 13 and 15, 2007. The replications were considered in this way since all plots were statistically similar in terms of soil physical characteristics prior to the experiment (Table 1).

Rain was applied with a rotating boom simulator (Lombardi Neto et al., 1979), covering two plots simultaneously. Three successive rainfalls, in $24 \mathrm{~h}$ intervals, were simulated at the following intensities: $1^{\text {st }}$ rain $30 \mathrm{~mm} / \mathrm{h}$, rain $2^{\text {nd }} 30 \mathrm{~mm} / \mathrm{h}$ and $3^{\text {rd }} 70 \mathrm{~mm} / \mathrm{h}$. The total precipitation of the first two rainfalls was $6 \mathrm{~mm}$ and of the last $12 \mathrm{~mm}$, corresponding to a total of $24 \mathrm{~mm}$.

\section{Application of ${ }^{15} \mathrm{~N}$}

Each plot was fertilized with a rate of $50 \mathrm{~kg} \mathrm{ha}^{-1} \mathrm{~N}$ as ammonium sulfate $\left[\left(\mathrm{NH}_{4}\right)_{2} \mathrm{SO}_{4}\right]$, with isotopic concentration of $5.09 \%$ of ${ }^{15} \mathrm{~N}$ atoms, $24 \mathrm{~h}$ before the first simulated rain. The quantity and form of application followed the concept of conventional application of $\left[\left(\mathrm{NH}_{4}\right)_{2} \mathrm{SO}_{4}\right.$ in sugarcane cultivation, applied in rows spaced $0.90 \mathrm{~m}$ apart. In this way, $13.5 \mathrm{~g}$ of fertilizer was applied by hand to a depth of $3 \mathrm{~cm}$, in a $3.5 \mathrm{~m}$ wide strip (Figure 1 ).

\section{Sample collection and analysis}

${ }^{15} \mathrm{~N}$ in the soil: Samples were collected in metal cylinders after the end of the experiment, i.e., after simulation of the three rainfalls. The cylinders were divided into representative samples of the 0-5 and $5-10 \mathrm{~cm}$ layer in the fertilizer application line. The remaining samples were collected only from the $0-5 \mathrm{~cm}$ layer, at distances of 3 and $6 \mathrm{~m}$ from the fertilizer application line (Figure 1).

Table 1. Soil physical characteristics prior to the experiment (surface layer of $10 \mathrm{~cm}$ )

\begin{tabular}{lcrccc}
\hline Plot & Clay & Silt & Sand & Moisture & Bd $^{(1)}$ \\
\hline \multirow{5}{*}{$\%$} & \multicolumn{5}{c}{ Untilled soil } \\
\cline { 2 - 6 } & & \multicolumn{5}{c}{$\mathrm{m}^{3} \mathrm{~m}^{3}$} & $\mathrm{~kg} / \mathrm{dm}^{3}$ \\
1 & 33.80 & 7.60 & 58.60 & 0.24 & 1.59 \\
3 & 33.20 & 7.30 & 59.50 & 0.25 & 1.50 \\
5 & 28.00 & 8.10 & 63.80 & 0.24 & 1.50 \\
& & & Tilled soil & \\
2 & 31.90 & 15.50 & 52.60 & 0.25 & 1.55 \\
4 & 30.80 & 9.60 & 59.60 & 0.23 & 1.55 \\
6 & 28.80 & 6.40 & 64.80 & 0.22 & 1.79 \\
\hline
\end{tabular}

(1) Bd: bulk density. Source: Bramorski et al. (2012).

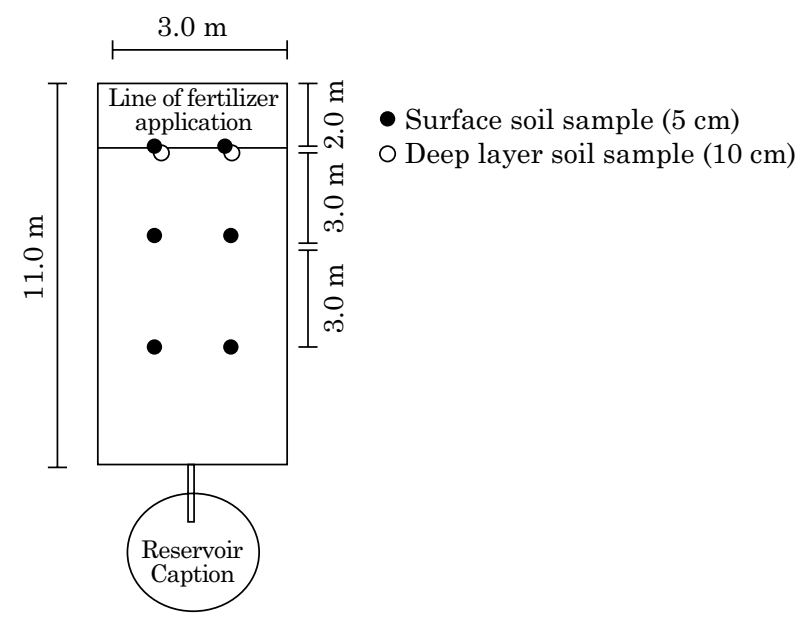

Figure 1. Diagram of the fertilizer application line and soil sampling. 
${ }^{15} \mathrm{~N}$ in sediment and water: after each simulated rainfall event the material of surface runoff (water + sediment) was collected.

The samples were filtered and an aliquot of each resulting solution was subjected to Kjeldahl digestion, as described by Bremner and Mulvaney (1982), to determine $\mathrm{N}$ concentration. The sediment retained on the filter was dried at $60^{\circ} \mathrm{C}$ for $24 \mathrm{~h}$ and then ground to determine total $\mathrm{N}$ and ${ }^{15} \mathrm{~N}$ abundance.

Nitrogen-15 abundance abundance was determined by mass spectrometry (Hydra 20-20, coupled to an ANCA-GSL automatic analyzer, of SerCon Co., Crewe, UK).

\section{Determination of fertilizer-derived N (FDN\%)}

The percentage of FDN and quantity of fertilizer-derived N (QFDN) for each sample type (soil-sediment and water) were calculated based on IAEA (1983).

The FDN\% was calculated as the relationship between the percentage of excess ${ }^{15} \mathrm{~N}$ atoms in the sample (atom $\%{ }^{15} \mathrm{~N}$ exc. samp.) and the percentage of excess ${ }^{15} \mathrm{~N}$ atoms in the fertilizer (atom $\%{ }^{15} \mathrm{~N}$ exc. fert,):

$$
F D N \%=\frac{(\% 15 N \text { exc.samp. })}{(\% 15 \mathrm{~N} \text { exc.fert. })} \times 100
$$

The QFDN $\left(\mathrm{kg} \mathrm{ha}^{-1} \mathrm{~N}\right)$ was calculated from the result of FDN\% and the total amount of $\mathrm{N}$ in the sample (QTN, kg ha-1 N):

$$
Q F D N=\frac{(\% F D N)}{100} \times Q T N
$$

The data were subjected to analysis of variance MANOVA (version 2.2) to detect statistically significant differences between the treatments and also between the ranges analyzed in each plot. Cluster analysis was applied in the ranges observed within plots.

\section{RESULTS AND DISCUSSION}

\section{Distribution of fertilizer-derived nitrogen (FDN) in the soil}

After simulation of cumulative rains of $24 \mathrm{~mm}$, the FDN that was not transferred in the soil in relation to the application in Untilled soil (US) varied from 1.94 to $16.63 \%$. In Tilled soil (TS), in this variation was between 0.26 and $15.16 \%$.

The FDN carried up to $3 \mathrm{~m}$ away from the application range ranged from 0.10 to $2.21 \%$ in US and 0.33 to $1.10 \%$ in TS. In the uttermost position, corresponding to $6 \mathrm{~m}$ away from the tracer application, the values were between 0.25 and $1.29 \%$ in US and 0.08 and $0.61 \%$ in TS. The MANOVA analysis of variance indicated significant differences in FDN transfer from application in the line, according to each treatment, in the three replications ( $\mathrm{p}$-value between 0.042 and 0.049) (Table 2).

Similarity groups were formed (Figure 2) for each distance, consisting of plots with the same tillage type, most evident at a distance of $3 \mathrm{~m}$ from the fertilizer line.

The plots 5 and 6 , consisting of US and TS respectively, had a clearly different pattern from the others. The formation of a similarity group between these plots was observed in the fertilizer line, as shown above (Figure 2a). These plots had a lower capacity of retaining FDN in the soil matrix, as demonstrated by the low concentration in the fertilizer line, with smaller decreases in the values with increasing distance from the line of application.

In the other plots, aside from the higher FDN concentration in the fertilizer line, the values found at a distance of $6 \mathrm{~m}$, in US, were around 13 and 49 times lower than those in the fertilizer line, while in TS they were around 24 and 100 times lower, indicating this type of soil tillage can delay the horizontal FDN transfer throughout the soil surface. Schick et al. (2000) demonstrated that in untilled soil, nutrients are accumulated in the soil surface, resulting from the surface application, or in shallow depth, of the soil fertilizer. According to Cogo (1981), in soils tilled conventionally along the full extension and to considerably deeper depths, surface roughness instantly becomes high, and sediment mobility during erosion is therefore

Table 2. Percentage of fertilizer-derived N (\%FDN) recovered from the fertilization line in Untilled

\begin{tabular}{|c|c|c|}
\hline \multirow{2}{*}{$\begin{array}{l}\text { Distance from the } \\
\text { fertilizer line }\end{array}$} & Untilled soil & Tilled soil \\
\hline & Plot 1 & Plot 2 \\
\hline $\mathrm{m}$ & \multicolumn{2}{|c|}{$\% \mathrm{FDN}$} \\
\hline 0 & 16.63 & 15.16 \\
\hline 3 & 2.21 & 1.11 \\
\hline \multirow[t]{3}{*}{6} & 1.29 & 0.62 \\
\hline & \multicolumn{2}{|c|}{$\mathrm{p}=0.042^{(1)}$} \\
\hline & Plot 3 & Plot 4 \\
\hline 0 & 12.38 & 14.18 \\
\hline 3 & 0.12 & 0.33 \\
\hline \multirow[t]{3}{*}{6} & 0.25 & 0.14 \\
\hline & \multicolumn{2}{|c|}{$\mathrm{p}=0.049$} \\
\hline & Plot 5 & Plot 6 \\
\hline 0 & 1.94 & 0.26 \\
\hline 3 & 0.11 & 0.37 \\
\hline \multirow[t]{2}{*}{6} & 0.43 & 0.09 \\
\hline & \multicolumn{2}{|c|}{$\mathrm{p}=0.043$} \\
\hline
\end{tabular}
(P1, P3 and P5) and Tilled plots (P2, P4 and P6)

(1) Value of $\mathrm{p}$ in relation to the level of significance. 
(a)

Cluster Tree

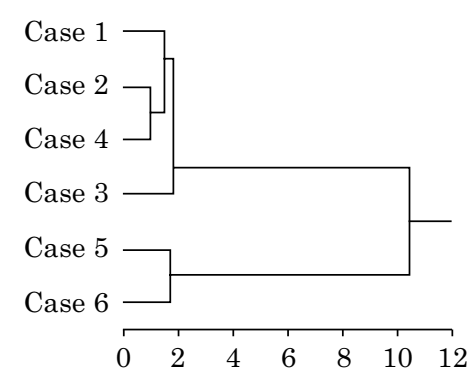

(b)

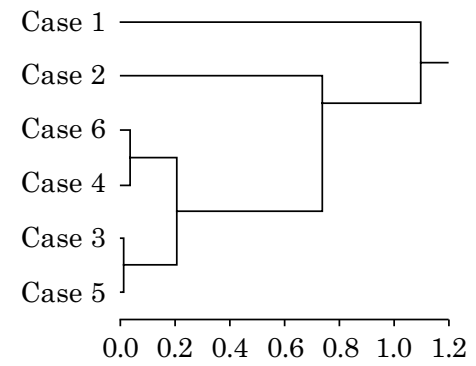

(c)

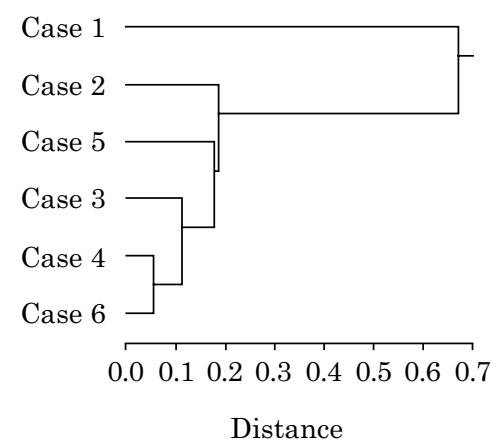

Figure 2. Grouping of the values found in the fertilizer line (a), at a distance of $3 \mathrm{~m}$ from the fertilizer line (b) and at a distance of $6 \mathrm{~m}$ from the fertilizer line (c), in all plots.

reduced. Giacomini et al. (2010) reported similar findings, i.e., a higher percentage of ${ }^{15} \mathrm{~N}$ in plots with minimum tillage than under conventional tillage.

In general, the concentrations of FDN transferred vertically in the soil were higher in deeper layers than those in the soil surface in the line of the tracer fertilizer. In the US plots (Figure 3), the FDN concentrations were higher in the plots than in deeper layers TS (Figure 3).

The plots 5 and 6 (US and TS, respectively) apparently had distinct pattern, with high vertical FDN transfer in the soil profile, as also observed before for the horizontal transfer.

\section{Loss of FDN in surface runoff}

In relation to sediment yield at the end of each rain, the highest intensity induced highest losses

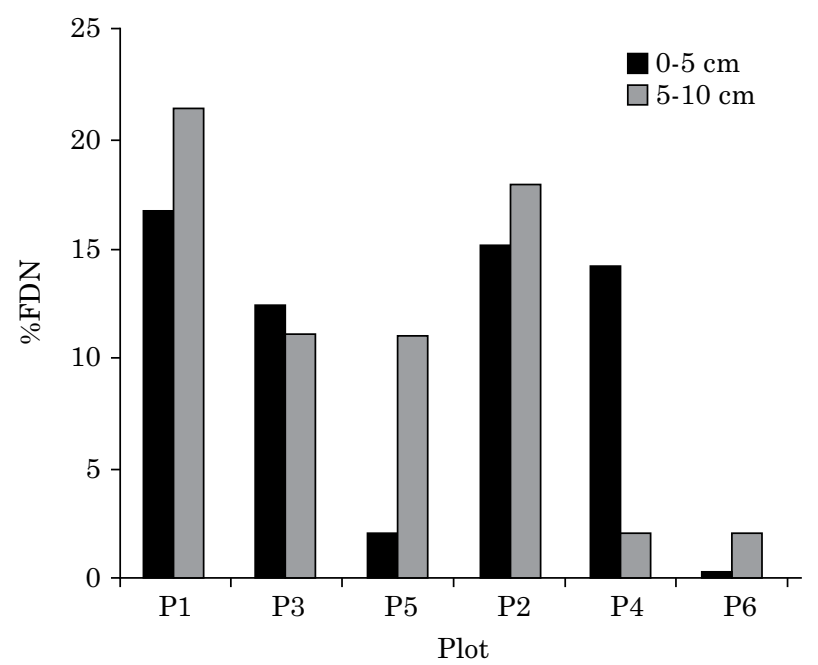

Figure 3. Percentage of fertilizer-derived nitrogen (\%FDN) in the 0-5 and 5-10 cm layers in Untilled plots (P1, P3 and P5) and Tilled plots (P2, P4 and P6).

from all plots, independent of the treatment, with exception of plot 2 (TS) (Table 3 ).

The rain intensity led to higher TN loss from all plots and soil tillage did not influence the losses, analyzing each rain separately. Berg et al. (1988) also stated an increase in $\mathrm{N}$ losses with increase in runoff volume, in tilled (conventional) as well as in untilled soil (no-tillage). Analyzing the total losses, the US plots tended to highest TN losses, as also stated by Giacomini et al. (2010) in plots under minimum tillage (without mechanical soil tillage), compared to plots under conventional tillage.

It can be concluded that the higher the soil loss, the higher is the TN loss.

However, when analyzing the fertilizer-derived $\mathrm{N}$ quantity (FDN), the FDN values were highest in TS plots. In other words, no direct relation between erosion rate and FDN transport was observed.

Bertol et al. (2003) stated that the increase in nutrient loss rates is generally inversely proportional to soil loss. Alberts and Moldenhauer (1981) explained that as erosion decreases, the proportion of minor particles in the eroded material increases. That is, the sediments become nutrient-richer.

Bellanger et al. (2004) also claimed that bare, untilled soils tend to lose more coarser particles, compared to cultivated or simply tilled soils. The coarsest sediments have a lower capacity of $\mathrm{N}$ transfer, which is mainly linked to the finer sediments.

The results confirmed these statements (Table 3). In general, the FDN concentrations decreased with each rainfall, whereas the quantity of eroded sediment increased. 
Table 3. Total eroded sediment, quantity of total nitrogen (TN) and fertilizer-derived N (FDN) and percentage of FDN in relation to TN (\%FDN) in each treatment, at the end of each rain, in Untilled and Tilled soils

\begin{tabular}{|c|c|c|c|c|c|c|c|c|c|c|c|c|}
\hline \multirow{4}{*}{$\begin{array}{l}\text { Rain intensity } \\
\mathrm{mm} / \mathrm{h}\end{array}$} & \multicolumn{3}{|c|}{ Total eroded sediment } & \multicolumn{3}{|c|}{ TN } & \multicolumn{3}{|c|}{ FDN } & \multicolumn{3}{|c|}{ FDN } \\
\hline & \multicolumn{9}{|c|}{$\mathrm{g}$} & \multicolumn{3}{|c|}{$\%$} \\
\hline & \multicolumn{9}{|c|}{ Replication } & & & \\
\hline & 1 & 2 & 3 & 1 & 2 & 3 & 1 & 2 & 3 & 1 & 2 & 3 \\
\hline & \multicolumn{12}{|c|}{ Untilled soil } \\
\hline 30 & 10.28 & 7.20 & 1.50 & 0.024 & 0.017 & 0.005 & 0.00043 & 0.00030 & 0.00018 & 1.80 & 1.79 & 3.38 \\
\hline 30 & 11.70 & 9.60 & 2.40 & 0.036 & 0.029 & 0.001 & 0.00106 & 0.00022 & 0.00002 & 2.95 & 0.76 & 1.87 \\
\hline 70 & 79.80 & 38.00 & 15.60 & 0.211 & 0.133 & 0.058 & 0.00034 & 0.00030 & 0.00015 & 0.16 & 0.23 & 0.26 \\
\hline \multirow[t]{2}{*}{ Total } & 101.78 & 54.80 & 19.50 & 0.271 & 0.179 & 0.064 & 0.00183 & 0.00082 & 0.00035 & 0.68 & 0.46 & 0.55 \\
\hline & \multicolumn{12}{|c|}{ Tilled soil } \\
\hline 30 & 6.90 & 0.78 & 1.28 & 0.016 & 0.002 & 0.007 & 0.00062 & 0.00010 & 0.00089 & 3.88 & 4.27 & 12.83 \\
\hline 30 & 7.36 & 1.35 & 6.90 & 0.027 & 0.004 & 0.023 & 0.00091 & 0.00010 & 0.00007 & 3.43 & 2.68 & 0.31 \\
\hline 70 & 5.94 & 13.77 & 28.05 & 0.028 & 0.027 & 0.110 & 0.00005 & 0.00002 & 0.00045 & 0.24 & 0.08 & 0.41 \\
\hline Total & 20.20 & 15.90 & 36.23 & 0.071 & 0.033 & 0.140 & 0.00158 & 0.00022 & 0.00141 & 2.33 & 0.67 & 1.01 \\
\hline
\end{tabular}

\section{Loss of fertilizer-derived N (FDN) in runoff water}

The low pressure of $\left(\mathrm{N}_{2}\right)$ gas in the mass spectrometer to determine total $\mathrm{N}$ and ${ }^{15} \mathrm{~N}$ abundance of the organic and mineral forms in the water (nitrate + nitrite + ammonium) revealed a low concentration of the element.

Within the scope of this experiment, water, as an important pathway of FDN loss in dissolved form, was not addressed in particular.

\section{Recovery of fertilizer-derived nitrogen (FDN) in the system}

The absence of crops in this experiment led to the high FDN concentrations in the soil ( $16.63 \%$ in US and $15.16 \%$ in TS, in the fertilizer line and $0-5 \mathrm{~cm}$ layer and 21.36 and $17.85 \%$ in US and $5.49 \%$ in TS in the $5-10 \mathrm{~cm}$ layer). Basanta et al. (2003) found only about $10 \%$ FDN incorporated in soil under sugarcane cultivation, after $128 \mathrm{~mm}$ rain in 100 days. Fenilli et al. (2008) found only $12.6 \%$ FDN in soil under coffee.

Several authors (Giacomini et al., 2010; Thomsen and Christensen, 2007; Rieger et al., 2008), compared the dynamics of $\mathrm{N}$ fertilizers in the soil-plant system under conventional and minimum tillage (without mechanical soil tillage) and stated no significant differences between the tillage methods, in terms of $\mathrm{N}$ plant uptake.

However, the dynamics of soil $\mathrm{N}$ and its soil-sediment relations (after erosion) show that the tillage methods induce different situations.

The highest retention of FDN in soil, in the fertilizer line and in the deeper layers was observed in the US plots. In these plots, the horizontal FDN transfer along the soil profile was also highest, and the losses associated to sediments were lowest, even though the soil losses by erosion were highest.

This could indicate that under this tillage type, most soil was lost in another way than by leaving the system via eroded sediment. Indices of higher FDN leaching to deeper soil layers, to beneath the $10 \mathrm{~cm}$ studied here, were observed. In addition, soil was possibly lost in runoff water. However, although the runoff volume was highest from these plots in all rain simulations, no FDN concentration was detected in the water, which may be the result of the low precipitation volume or of the volatilization of the more soluble $\mathrm{N}$ after the first rain.

With regard to FDN, exportation by erosion was more efficiently minimized from untilled soils, even though this efficiency was not observed in terms of soil loss.

Guadagnin et al. (2005) stated that systems of soil conservation management were more efficient than those of conventional management in reducing losses of soil, water and mineral N. To some extent, this confirms our study results, with exception of soil losses, which were higher from US, most likely due to the absence of a residue cover, which was not the case in the study of the said authors.

\section{CONCLUSIONS}

The absence of soil tillage led to higher soil erosion losses by the applied rainfalls, and to higher losses of total nitrogen, found mainly in organic form, associated to the finer soil minerals in the soil. 
The losses of fertilizer-derived $\mathrm{N}$ were however higher from plots with tilled soil, indicating that the lost, highly soluble fertilizer, is not directly associated with the quantity of eroded sediment.

The rain intensity influenced soil and TN losses; the most intense rainfall induced highest losses, in US as well as in TS. However, rain intensity had no influence on FDN losses; losses were highest under the least intense rainfalls in both applied treatments.

The plots with untilled soil retained FDN more efficiently, horizontally as well as vertically and, less efficiently in terms of minimizing total soil and nitrogen loss.

\section{ACKNOWLEDGEMENTS}

The authors are indebted to the Brazilian Council for Scientific and Technological Development (CNPq), for the doctoral scholarship of the first author; to the State of São Paulo Research Foundation (Fapesp) for the research grant; to the Brazilian Agricultural Research Corporation (Embrapa) Southeastern Region Agriculture and Embrapa Agricultural Instrumentation for the support with equipment and infrastructure; to the Agronomic Institute of Campinas (IAC) for lending us a rain simulator apparatus; and to the Center of Nuclear Energy in Agriculture (CENA/USP) for the analyses of ${ }^{15} \mathrm{~N}$ yield and for providing isotope-marked fertilizer.

\section{REFERENCES}

Alberts EE, Moldenhauer WC. Nitrogen and phosphorus transported in eroded soil aggregates. Soil Sci Soc Am J. 1981;45:391-6.

Antweiler RC, Goolsby DA, Taylor HE. Nutrients in the Mississippi River. In: Meade RH, editor. Contaminants in the Mississippi River. Reston: 1996.

Bellanger B, Huon S, Velasquez F, Valle V, Girardin C, Mariott A. Monitoring soil organic carbon erosion with ${ }^{13} \mathrm{C}$ and ${ }^{15} \mathrm{~N}$ on experimental field plots in the Venezuelan Andes. Catena. 2004;58:125-50.

Berg WA, Smith SJ, Coleman GA. Management effects on runoff, soil, and nutrient losses form highly erodible soils in the Southern plains. J Soil Water Conserv. 1988;37:407-10.

Bertol I, Mello EL, Guadagnin JC, Zaparolli ALV, Carrafa MR. Nutrients losses by water erosion. Sci Agric. 2003;3:581-6.

Bertol OJ, Rizzi NE, Favaretto N, Lavoranti OJ. Perdas de nitrogênio via superfície e subsuperfície em sistema de semeadura direta. Floresta. 2005;35:429-41.

Bertol OJ, Rizzi NE, Bertol I, Roloff G. Perdas de solo e água e qualidade do escoamento superficial associadas a erosão entre sulcos em área cultivada sob semeadura direta e submetida as adubações mineral e orgânica. R Bras Ci Solo. 2007;31:781-92.

Beutler AN, Centurion JF, Centurion MAPC, Silva AP. Efeito da compactação na produtividade de cultivares de soja em Latossolo Vermelho. R Bras Ci Solo. 2006;30:787-94

Bramorski J, De Maria IC, Lemos E, Silva R, Crestana S. Relations between soil surface roughness, tortuosity, tillage treatments, rainfall intensity and soil and water losses from a Red Yellow Latosol. R Bras Ci Solo. 2012;36:1291-7.

Bremner JM, Mulvaney CS. Nitrogen total. In: Page AL, Miller RH, Keney DR, editors. Methods of soil analysis. Chemical and microbiological properties. $2^{\text {nd }}$.ed. Madison: America Society of Agronomy; 1982. v.2. p.595-624. (Agronomy, 9).

Cardoso D, Silva MLN, Freitas DAF, Avanzi JC. Plantas de cobertura no controle das perdas de solo, água e nutrientes por erosão hídrica. R Bras Eng Agric Amb. 2012;16:632-8.

Carranca C, De Varennes A, Rolston DE. Variation in N-recovery of winter wheat under Mediterranean conditions studied with ${ }^{15} \mathrm{~N}$-labelled fertilizers. Eur J Agron. 1999;11:145-55.

Cassol EA, Lima VS. Erosão em entressulcos sob diferentes tipos de preparo e manejo do solo. Pesq Agropec Bras. 2003;38:117-24.

Choi W, Ro H, Hobbie EA. Patterns of natural ${ }^{15} \mathrm{~N}$ in soils and plants from chemically and organically fertilized uplands. Soil Biol Biochem. 2003;35:1493-500.

Cogo NP. Effect of residue cover, tillage induced roughness, and slope length on erosion and related parameters [tese]. West Lafayette: Purdue University; 1981.

Cogo NP, Levien R, Schwarz RA. Perdas de solo e água por erosão hídrica influenciadas por métodos de preparo, classes de declividade e níveis de fertilidade do solo. R Bras Ci Solo. 2003;27:743-53.

Delgado JA, Shaffer MJ, Lal H, Mckinney S, Gross CM, Cover H. Assessment of nitrogen losses to the environment with a Nitrogen Trading Tool (NTT). Comp Electron Agric. 2008;63:193-206.

Döbereiner J. A importância da fixação biológica de nitrogênio para a agricultura sustentável. R Biotecnol Ci Desenv. 1997;1:2-3.

Empresa Brasileira de Pesquisa Agropecuária - Embrapa. Sistema brasileiro de classificação de solos. $3^{\text {a }}$.ed. Brasília: 2013.

Favaretto N. Gypsum amendment and exchangeable calcium and magnesium related to water quality and plant nutrition [tese]. West Lafayette: Purdue University; 2002.

Fenilli TAB, Reichardt K, Favarin JL, Bacchi O, Silva AL, Timm LC. Fertilizer ${ }^{15} \mathrm{~N}$ balance in a coffee cropping system: a case study in Brazil. R Bras Ci Solo. 2008;32:1459-69.

Follett RF, Walker DJ. Groundwater quality concerns about nitrogen. In: Follett RF, editor. Nitrogen management and groundwater protection. Amsterdam: Elsevier Science Publication; 1989. p.1-22.

Giacomini SJ, Machet JM, Boizard H, Recous S. Dynamics and recovery of fertilizer ${ }^{15} \mathrm{~N}$ in soil and winter wheat crop under minimum versus conventional tillage. Soil Till Res. 2010;108:51-8.

Guadagnin JC. Perdas de nutrientes e carbono orgânico pela erosão hídrica, em um Cambissolo Húmico Alumínico léptico submetido a diferentes sistemas de preparo e cultivo do solo [dissertação]. Lages: Universidade do Estado de Santa Catarina; 2003. 
Guadagnin JC, Bertol I, Cassol PC, Amaral AJ. Soil, water and nitrogen losses through erosion under different tillage systems. R Bras Ci Solo. 2005;29:277-86.

International Atomic Energy Agency - IAEA. A guide to the use of nitrogen 15 and radioisotopes in studies of plant nutrition: calculations and interpretation of data. A technical document issued by the International Atomic Agency. Vienna: IAEATECDOC-288; 1983.

Lombardi Neto F, Castro OM, Silba IR, Bertoni J. Simulador de chuva e sua aplicação em pesquisas de erosão do solo. Agronômico. 1979;31:81-98.

Mead DJ, Chang SX, Preston CM. Recovery of ${ }^{15} \mathrm{~N}$-urea 10 years after application to a Douglas-fir pole stand in coastal British Columbia. For Ecol Manage. 2008;256:694-701.

Mehl HU. Caracterização de padrões de chuva ocorrentes em Santa Maria (RS) e sua relação com as perdas de solo e água em entressulcos [dissertação]. Santa Maria: Universidade Federal de Santa Maria; 2000.

Panachuki E, Bertol I, Alves Sobrinho T, Oliveira PTS, Rodrigues DBB. Perdas de solo e de água e infiltração de água em Latossolo vermelho sob sistemas de manejo. $\mathrm{R}$ Bras Ci Solo. 2011;35:1777-85.
Reichardt K, Bacchi OOS. Isotopes in soil and plant investigations. In: Hillel D, editor. Encyclopedia of soils and the environment. Amsterdam: Elsevier; 2004. v.1. p.280-4.

Rieger S, Richner W, Streit B, Frossard E, Liedgens M. Growth, yield, and yield components of winter wheat and the effects of tillage intensity, preceding crops, and $\mathrm{N}$ fertilization. Eur J Agron. 2008;28:405-11.

Schick J, Bertol I, Batistela OAA, Balbinot Júnior AA. Erosão hídrica em Cambissolo húmico alumínico submetido a diferentes sistemas de preparo e cultivo do solo. I. Perdas de solo e água. $\mathrm{R}$ Bras Ci Solo. 2000;24:427-36.

Thomsen IK, Christensen BT. Fertilizer ${ }^{15} \mathrm{~N}$ recovery in cereal crops and soil under shallow tillage. Soil Till Res. 2007;97:117-21.

Vallano DM, Sparks JP. Foliar ${ }^{15} \mathrm{~N}$ is affected by foliar nitrogen uptake, soil nitrogen, and mycorrhizae along a nitrogen deposition gradient. Oecologia. 2013;172:47-58.

Woodward DW, Potito AP, Beilman DW. Carbon and nitrogen stable isotope ratios in surface sediments from lakes of western Ireland: implications for inferring past lake productivity and nitrogen loading. J Paleolimnol. 2012;47:167-84. 